\title{
A Flipped Learning Approach Using Social Media in Health Informatics Education
}

\author{
Ali H. Alharbi \\ Department of Health Informatics, College of Public Health and Health Informatics, Qassim University, Qassim, \\ Saudi Arabia \\ Email:ahhrbie@qu.edu.sa
}

Received 29 June 2015; accepted 2 August 2015; published 5 August 2015

Copyright (C) 2015 by author and Scientific Research Publishing Inc.

This work is licensed under the Creative Commons Attribution International License (CC BY).

http://creativecommons.org/licenses/by/4.0/

(c) (i) Open Access

\section{Abstract}

Social media have become an important aspect of people's everyday life. Despite the popularity of social media networks and applications, only few educators utilize them to improve teaching and learning. A flipped learning is an innovative approach that changes the traditional way of delivering lectures in the classroom by inverting the instructional cycle so that students can gain knowledge before the class. This paper presents a flipped learning approach for teaching using social media. Students were exposed to the lecture content before the class in a collaborative and interactive learning environment using a well-known social media application. The course instructor served as a facilitator rather than a dominator for the instructional process. The proposed approach was applied to teach an undergraduate introductory course on health informatics, a dynamic and emerging academic discipline. In this paper, a focus group research technique was utilized to evaluate the educational effectiveness of this approach. The results of the evaluation revealed that students were comfortable and satisfied that this approach helped them understand the course concepts in an interactive and collaborative learning environment. The results of the study also identified some educational benefits as well as limitations and drawbacks of using social media as a flipped learning approach. These results can provide an educational framework to improve the implementation of flipped learning approaches using social media.

\section{Keywords}

Flipped Learning, Social Media, Health Informatics Education

\section{Introduction}

Web-based technologies that encourage users to be more socially active in their communities have been receiv- 
ing increased attention. As put forward by Bruns (2008), "the World Wide Web has been radically transformed, shifting from an information repository to a more social environment where users are not only passive receivers or active harvesters of information, but also creators of content” (p. 22).

Social media have been defined as "a category of online media where people are talking, participating, sharing, networking, and bookmarking online. Most social media services encourage discussion, feedback, voting, comments, and sharing of information from all interested parties. It's more of a two-way conversation, rather than a one-way broadcast like traditional media” (Jones, 2009). According to Bryer and Zavattaro (2011), social media are described as "technologies that facilitate social interaction, make possible collaboration, and enable deliberation across stakeholders".

As educators strive to adopt new instructional approaches to encourage and motivate students to learn, social media can be one of the best candidates. Also, blended learning is possible by using social media as complement distance education environments and thus bridging the gap between technology and pedagogy (Brady, Holcomb, \& Smith, 2010; Lee \& McLoughlin, 2010; Veletsianos \& Navarrete, 2012). However, despite the popularity of using social networks, only few educators used them to support teaching and learning (Lenhart, Purcell, Smith, \& Zickuhr, 2010).

Flipped learning is one of the emerging instructional approaches that can help achieve a blended learning environment. Flipped (or inverted) learning is a new form of blended learning in which the traditional instructional cycle is inverted so that lecture contents are moved outside the classroom allowing for more practice and interactions inside the classroom (Strayer, 2012).

This paper aims to investigate the potential benefits and limitations of using social media applications as a flipped learning approach in teaching health informatics courses. The flipped classroom activities in the study reported in this paper focus on improving the abilities of students to discuss topics in a collaborative and interactive learning environment. The course instructor serves as a facilitator rather than a dominator of the learning process. The instructor initiates the discussion by asking a question and presenting students with a short video related to the content of the next lecture. After that, students need to post their contributions using the social application so that other members can comment on them. The interaction process follows a semi-structured approach in which a large part of the discussion is based on students' answers and responses rather than predetermined by the instructor.

The rest of the paper is structured as follows. Section 2 provides a theoretical background to the study. Section 3 presents a review of relevant literature. Section 4 describes the proposed flipped learning approach in details, and outlines the research methodology adopted to evaluate the educational effectiveness of the proposed approach. Section 5 presents an analysis and discussion of the results. Finally, Section 6 concludes the paper and presents recommendations.

\section{Theoretical Background}

\subsection{What Is a Flipped Learning?}

Educators strive to come up with new teaching and learning approaches to cope up with the evolving requirements and preferences of learners. The advancement of information technology has affected the way we teach and learn and thus provides opportunities to enrich the learning environment.

The Flipped Learning is a relatively new model of instruction that has the potential to alter the traditional way of delivering the learning material to achieve more effective learning outcomes. First, it is relevant to provide a comprehensive definition for the term Flipped Learning in order to give the reader the big picture behind this approach. The term Flipped Learning is defined as a "pedagogical approach in which direct instruction moves from the group learning space to the individual learning space, and the resulting group space is transformed into a dynamic, interactive learning environment where the educator guides students as they apply concepts and engage creatively in the subject matter" (Flipped Learning Network, 2014). This definition stresses the importance of interactive and flexible rather than passive form of instruction. It also highlights the role of the educator as a facilitator rather than a dominator for the learning process. Instructors guide students to engage in activities that lead to better learning outcomes. The Flipped Leaning Network has established the Four Pillars of FLIP ${ }^{\circledR}$ to describe the flipped learning (Flipped Learning Network, 2014). These pillars are Flexible Environment, Learning Culture, Intentional Content, and Professional Educator. The first pillar stresses the importance of flipped learning to allow for a variety of learning and instruction models to accommodate the requirements of students. In the 
second pillar, learning culture, the instruction is shifted from the traditional teacher-censed approach in which teachers dominate the learning environment and they are the only sources of information to a learner-centered approach in which students are not passive receivers of information but active participants in the learning environment. The third pillar, intentional content, highlights the role of educators in exploring, preparing and delivering high-quality learning content based on what students really need to learn and not only based on teachers' preferences. Finally, the fourth pillar concerns the role of professional educators in the implementation of flipped learning. They act as facilitators by continuously observing how students learn and providing students with instant feedback. Table 1 summarizes the differences between the flipped and the traditional learning.

Flipped learning has many advantages over the traditional learning. Stone (2012) listed a number of advantages for flipped learning in higher education. These advantages are summarized in the following:

- Development of life-long learners: the encouragement of students to learn the content before attending the class helps them to develop and apply different learning strategies. Students watch videos in their own pace and continuously self-assess their knowledge.

- Increased engagement in the learning material: in the traditional learning environment, class time is devoted to the delivery of learning material, which limits the time for active interaction of students with the learning content. In the flipped learning environment, students are encouraged to be active participants in the leaning process by interacting with the learning material, asking questions, and receiving personalized and instant feedback.

- Enhanced interaction between student and faculty: flipped learning activities can remove barriers between faculty and students, which in turn enhances the interaction between them. The instructor becomes a facilitator for the learning process rather than being dominant all the time.

\subsection{Health Informatics Education}

Health informatics, a new emerging academic discipline, is an area that has been receiving increased attention in the last few years due to the movement of healthcare organizations towards adopting e-health strategies. Health informatics, as defined by the US National Library of Medicine, is "the interdisciplinary study of the design, development, adoption, and application of IT-based innovations in healthcare services delivery, management, and planning” (Murray, Paton, Hansen, Elkin, \& Fernandez-Luque, 2011). Students from different backgrounds and knowledge may choose to join health informatics academic programs. Therefore, teaching and learning health informatics is complex and challenging. Worldwide, academic institutions have been establishing new health informatics academic programs in the undergraduate and graduate levels. Like any other emerging discipline, developing curriculum and instructional approaches is not an easy task. A lot has to be done to provide support for teachers and students in health informatics programs.

Potential students in the majority of health informatics programs come from two different backgrounds: information technology (IT) and health science. The academic program needs to be tailored to both groups in order to meet the interdisciplinary nature of the field of health informatics. If students are IT professionals, they may need more training on healthcare systems and clinical settings. For healthcare professionals, it is essential for them to broaden their knowledge and experience in dealing with health information systems.

Formal efforts to establish frameworks for health informatics education have started only recently. Recommendations of the International Medical Informatics Association (IMIA) on health informatics education (Mantas et al., 2010) stress the importance of preparing students to be self-regulated learners to cope up with

\section{Table 1. Comparisons between in the traditional learning and the flipped learning.}

\begin{tabular}{|c|c|c|}
\hline Criteria & Traditional learning & Flipped learning \\
\hline Learning cycle & $\begin{array}{l}\text { Teacher-centered approach. } \\
\text { Students passively listen to lectures in class. }\end{array}$ & $\begin{array}{l}\text { Student-centered approach. } \\
\text { Pre-class activities (videos/discussion boards). }\end{array}$ \\
\hline Teachers & $\begin{array}{l}\text { Dominants and control the learning environment. } \\
\text { Create the learning material. }\end{array}$ & $\begin{array}{l}\text { Facilitators for the learning process. } \\
\text { Students can contribute to the learning material. }\end{array}$ \\
\hline Students & $\begin{array}{l}\text { Passive learners. } \\
\text { All students follow predetermined paths for learning. }\end{array}$ & $\begin{array}{l}\text { Active participants. } \\
\text { Personalized and flexible learning paths. }\end{array}$ \\
\hline $\begin{array}{l}\text { Learning } \\
\text { environment }\end{array}$ & $\begin{array}{l}\text { Rigid and difficult to customize. } \\
\text { Limited use of information technology. }\end{array}$ & $\begin{array}{l}\text { Flexible and adaptive. } \\
\text { Innovative adoption of information technology. }\end{array}$ \\
\hline
\end{tabular}


the dynamic nature of the health informatics discipline. The recommendations established a framework that consists of a number of competencies categories under broad categories. These competencies help institutions and educators ensure that the courses provide students with the required knowledge and skills to success as health informatics professionals. The Australian Health Informatics Education Council (AHIEC) has also established a framework to guide health informatics education in the country and worldwide. The framework focuses on defining the scope, careers and competencies for different areas of health informatics. Similar efforts were also established by the Canadian Health Informatics Association (COACH), which developed a set of competencies categorized into a number of domains to reflect the broad knowledge and skills required for health informatics professionals to work effectively.

\section{Literature Review}

\subsection{Social Media in Education}

Many studies reported the willingness and motivation of students to use social media to improve their learning experience (Lenhart et al., 2010; Liu, 2010; Poellhuber, Anderson, \& Roy, 2011). A review of the literature related to the use of social media for academic purposes (Guy, 2012) revealed that educators are using social media as an instructional approach to achieve blended learning environments. In addition, the study found that social media has been utilized by educators to help students acquire participatory and collaborative skills, as well as giving them the opportunity for self-expression, self-reflection and social interaction.

To the best of my knowledge after reviewing relevant literature, there is a limited research in using social media in health informatics education. However, there is a reasonable number of studies that discussed the role of social media in medical education.

Cheston, Flickinger, and Chisolm (2013) conducted a systematic literature review of the published studies on the use of social media interventions in medical education. The purpose of the study was to get insight into the influence of these interventions on the satisfaction, attitudes, and skills for physicians and physicians-in-training, and to outline challenges and opportunities educators encounter during the implementation of these interventions. The study found that the use of social media interventions in the reviewed studies was associated with improved knowledge, attitudes, and skills. The study also revealed that the most common cited opportunities were promoting learners' engagement, feedback, and personal development. The most challenges reported by the review paper include variation in students' participation, privacy and security issues, and some technical problems. The study concludes that the use of social media in medical education is still in its infancy and more research is essential, especially in areas related to opportunities and challenges in adopting this technology.

Another social media approach using twitter was reported in (Bahner et al., 2012). The authors used "push technology" via Twitter and Facebook to deliver medical educational content to mobile devices.

The International Medical Informatics Association has established a special interest group known as the Social Media Working Group (IMIA’s SMWG) (Paton, Bamidis, Eysenbach, Hansen, \& Cabrer, 2011) to serve as a vehicle to promote research related to the use of social media in the field of medical and health informatics. Even though the focus of the IMIA's SMWG was not directly related to education, research published through the group addresses some potential benefits of using social media in supporting health and medical informatics education. A workshop organized by the working group during the International Conference of the European Federation for Medical Informatics (MIE 2011) discussed the ways in which social media are currently used in healthcare and academia (Murray et al., 2011). Paton et al. (2011) contributed to the IMIA SMWG by reporting on the anecdotal opinions of five educators who used social media to teach medical and health subjects. The authors believed that it is difficult to draw conclusions on the educational effectiveness of social media in medical and health education due to the limited number of studies conducted in this area.

\subsection{The Educational Effectiveness of Flipped Learning}

This section outlines empirical evidences from the literature on the effectiveness of flipped learning in supporting students' learning and engagement in higher education. The review is limited to the disciplines that overlap with health informatics, such as public health, information systems and computer science.

Galway, Corbett, Takaro, Tairyan, and Frank (2014) reported on the design, implementation and evaluation of a flipped learning approach in teaching public health students. The study used a pre-post survey to measure 
changes in students' perceived knowledge. In addition, the study compared standard reviews and examination scores for the flipped learning approach group to previous offerings of the same course when the course was taught using a lecture-based method. A focus group session was conducted also to gain more in-depth understanding of students' perceptions and experiences. The results of the study revealed positive learning experiences and perceptions toward the proposed flipped learning approach compared to the traditional instructional approach. In (McLaughlin et al., 2014) the authors reported on their experience of flipping a pharmaceutics course in which they offered lectures as self-paced online videos and devoted class time for active learning exercises. The study compared the course evaluation responses between the flipped learning approach and the traditional format of the course. Students in the flipped learning group were most likely to report positive experiences and perceptions toward the educational effectiveness of the instructional approach compared to the students who completed the course in the traditional format.

In computer science and information technology education, few studies have reported the use of flipped learning to improve the teaching and learning. For example, Amresh, Carberry, and Femiani (2013) discussed the results of the implementation of flipped learning activities in teaching an introductory programming course. The flipped learning activities comprise online video quizzes that aim at improving students' learning outcomes. The study compared the performance of students who were required to complete these video quizzes to evaluate their pre-requisite knowledge for the next lecture topics and activities with other students who were not required to complete such videos. The results of the study did not support the hypothesis of the study, which claimed that the pre-class video quizzes would improve students' grades in introductory programming courses. According to the study, the surprising result was due to many factors such as the failure of these video quizzes to support deep learning. In (Xu, 2013) the author reported on the results of reforming a course about mobile application development using a flipped learning approach. The course focused on training students on self-learning and assessment of their progress before class using videos and other materials prepared by teachers. During the class, students engaged in discussions and shared their learning experiences with each other. The result of the evaluation of the reformed course was positive; students demonstrated high-level of knowledge about the concepts covered in the course.

\section{Social Media as Flipped Classroom Approach: A Proposed Framework in Teaching Health Informatics}

This section provides detailed description of the study that was conducted to investigate the potential of using social media to achieve a flipped learning environment in health informatics education. The objectives of the study can be summarized in the following:

- Exploring students' perceptions towards using a social media application in a flipped learning environment.

- Discovering potential benefits and limitations of this approach.

\subsection{Course and Participants}

The proposed method was applied in an introductory course about electronic health records (EHRs) at [Qassim University, Saudi Arabia]. The course gives students general information about the concepts and terms related to EHRs and their roles in healthcare organizations. The course covers various topics including introduction to EHRs, features and standards. An important part of the course is also to give students the chance to have hands-on experience on dealing with a real EHR system. The final sample size was 14 students.

\subsection{Learning Resources and Activities}

The proposed teaching approach in this study utilizes one of the well-known social networking applications that have been used by students almost every day. WhatsApp (WhatsApp Inc., 2015) is a social networking application that allows users to send instant messages to their contacts. The messages can include different media types such as audio and video. Table 2 outlines the learning resources that were used to implement the flipped learning approach distributed based on the topics covered in the introductory electronic health records course. The table also summarizes the activities in which students were engaged for each topic.

\subsection{Study Design and Methodology}

This study aims to explore the educational effectiveness of using social media as a flipped learning approach to 
Table 2. Summary of the learning resources and activities that were used during the flipped learning approach.

\begin{tabular}{|c|c|c|}
\hline Topics & Learning resources & Activities \\
\hline $\begin{array}{l}\text { Introduction to } \\
\text { the course and the } \\
\text { flipped learning } \\
\text { activities }\end{array}$ & $\begin{array}{l}\begin{array}{c}\text { Flipping the classroom: } \\
\text { simply speaking }\end{array} \\
\text { https://www.youtube.com/watch?v=26px } \\
\text { h qMppE }\end{array}$ & $\begin{array}{l}\text { - Creating the discussion group and adding members. } \\
\text { - } \quad \text { Introducing the discussion policies. } \\
\text { Description of the benefits for participating in the activities. }\end{array}$ \\
\hline $\begin{array}{l}\text { Introduction to } \\
\text { electronic health } \\
\text { records (EHRs) }\end{array}$ & $\begin{array}{l}\text { What is electronic medical record } \\
\text { (EMR)? } \\
\text { http://www.youtube.com/watch?v=MOw } \\
\underline{\text { ML1N3TpM }}\end{array}$ & $\begin{array}{l}\text { - The instructor initiated the discussion by posting a link to a } \\
\text { simple YouTube video that introduces the concept of Electronic } \\
\text { Medical Records in a simple and interesting way. } \\
\text { - The instructor then asked a number of questions to encourage } \\
\text { students to watch and listen to the introductory video. Students } \\
\text { can answer the questions at any time. }\end{array}$ \\
\hline $\begin{array}{l}\text { Differences } \\
\text { between EMR } \\
\text { and EHR }\end{array}$ & $\begin{array}{c}\text { Summary of differences between EMR } \\
\text { and EHR } \\
\text { http://youtu.be/y85HfTG4UpU }\end{array}$ & $\begin{array}{l}\text { - The instructor initiated the flipped learning activity by posting the } \\
\text { following question. "Are EMR and EHR the same? Why?" } \\
\text { - Students were encouraged to give personal answers based on their } \\
\text { understanding of the differences between the two terms. } \\
\text { - The teacher posted a link to a short video that summarizes the } \\
\text { differences between EMR and EHR in a simple and interesting } \\
\text { way. }\end{array}$ \\
\hline $\begin{array}{l}\text { Standards and } \\
\text { features of EHR }\end{array}$ & $\begin{array}{l}\text { HITECH act: electronic health records } \\
\text { and meaningful use } \\
\text { http://youtu.be/GzeUKKWvC0o }\end{array}$ & $\begin{array}{l}\text { - Students engaged in a discussion on why do we need to follow } \\
\text { standards in our daily life. } \\
\text { - The instructor then gave some examples of standards and asked } \\
\text { students to list their benefits. } \\
\text { - Finally, students watched a video posted by the instructor about } \\
\text { one of the main standards that was established to support } \\
\text { meaningful use of health information technology. }\end{array}$ \\
\hline $\begin{array}{l}\text { Self-assessment } \\
\text { tools }\end{array}$ & Quizlet website and mobile app & $\begin{array}{l}\text { - The instructor showed students how they can search and find } \\
\text { relevant online quizzes and study tools that allow them to } \\
\text { self-assess their understanding of different topics. }\end{array}$ \\
\hline $\begin{array}{c}\text { Privacy and } \\
\text { security issues }\end{array}$ & $\begin{array}{l}\text { Case studies and real life examples } \\
\text { involving security and privacy issues } \\
\text { related to the implementation and } \\
\text { adoption of EHRs. }\end{array}$ & $\begin{array}{l}\text { - The teacher initiated the discussion by sharing with the students } \\
\text { some real world stories and case studies describing some security } \\
\text { and privacy problems that arise as a result of using EHRs. } \\
\text { - The instructor then encouraged students to come up with portals } \\
\text { and services implemented by government agencies to provide } \\
\text { eservices for the consumer. } \\
\text { - Students then were asked to comment on these portals and } \\
\text { services in terms of potential privacy and security issues. }\end{array}$ \\
\hline $\begin{array}{l}\text { Potential } \\
\text { development in } \\
\text { the future } \\
\text { of EHR }\end{array}$ & $\begin{array}{c}\text { Personal EHR } \\
\underline{\text { https://www.youtube.com/watch?v=A_I_ }} \\
\underline{\text { wYJNZM8 }}\end{array}$ & $\begin{array}{l}\text { - Students watched a video about an initiative by the Australian } \\
\text { government to implement a personal eHealth record system. } \\
\text { Finally, the teacher concluded the session by encouraging } \\
\text { students to come up with features that they think are the most } \\
\text { important to be implemented in the national personal eHealth } \\
\text { system. }\end{array}$ \\
\hline
\end{tabular}

improve health informatics education, and thus the study is exploratory and descriptive in nature. At the end of the study, qualitative data collection methods were utilized to measure the educational effectiveness of this approach as follows:

- A focus group consisting of all students participated in the flipped classroom activities $(n=14)$. The focus group is a data collection technique that relies on interviews with a small group of participants in a collaborative and interactive session rather than individually. The focus group can be defined as "a small gathering of individuals who have a common interest or characteristic, assembled by a moderator, who uses the group and its interactions as a way to gain information about a particular issue” (Williams \& Katz, 2001). At the end of the course, students were invited to participate in an interactive session to gather feedback on their experience of the flipped learning activities, including benefits and difficulties. The session lasted for about 30 minutes.

- An analysis of the interaction in the discussion group. The analysis was performed at the end of each activity and at the end of course. The social medial application allows the entire group discussion to be exported as a 
text file, which makes it easy for further analysis. The interaction analysis aims at discovering issues that could prevent students from providing effective contributions.

\subsection{Procedure}

The flipped learning activities lasted for about 8 weeks. The activities focused on improving the abilities of students to discuss topics in a collaborative and interactive environment (Table 2). The course instructor served as a facilitator rather than a dominator for the instructional process. The instructor initiates the discussions by presenting students with an example from the real life and a short video related to the content of the next lecture. This helps students grasp the big picture of the topic more quickly. After that, students need to post their contributions using the social media application so other members can comment on them. The interaction process follows a semi-structured approach in which a large part of the discussion was based on students' answers and responses rather than pre-determined by the instructor.

As shown in Table 2, the first activity involved an introduction to the flipped learning approach, including the social media platform and whether all students have it downloaded on their smartphone or not. The instructor also introduced students to the policies of the discussions and what he expects from them during the activities. The instructor stressed the fact that participating in the activity is voluntarily, and their contributions will not be evaluated or marked. The instructor then created a group using WhatsApp social media application and added the participated students to this group.

The activities were divided by topics, each which will be covered during the next lecture that follows the activity. Each activity took places in the week before the actual lecture and consisted of about 3 sessions, each lasted for about 30 minutes. In some cases, students were not online at the same time; however, they can contribute to the discussion by posting their thoughts at any time. Figure 1 outlines the cycle of the flipped learning approach proposed in this study.

\section{Results and Discussion}

To help guide the analysis of the results, let us first restate the aim and objectives of the study. The study aims to shed light into how students perceive the use of social media in a flipped learning environment to improve an introductory health informatics course. The main objectives of the study were to identify potential benefits and drawbacks of this approach from the students' point of views.

Constant Comparison Analysis framework (as cited in Onwuegbuzie, Dickinson, Leech, \& Zoran, 2009) was employed to elect possible themes and categories from the focus group data. Figure 2 depicts the major stages in the constant comparison analysis (Kolb, 2012). First, the researcher goes through the data and attach a descriptor to each chunk of data (i.e., open coding). In this stage, the researcher continuously compares and contrasts the data. In the second stage (i.e., axial coding), these descriptors or codes are grouped into some categories. The researcher identifies links and common features between the data to create categories. Finally, in the

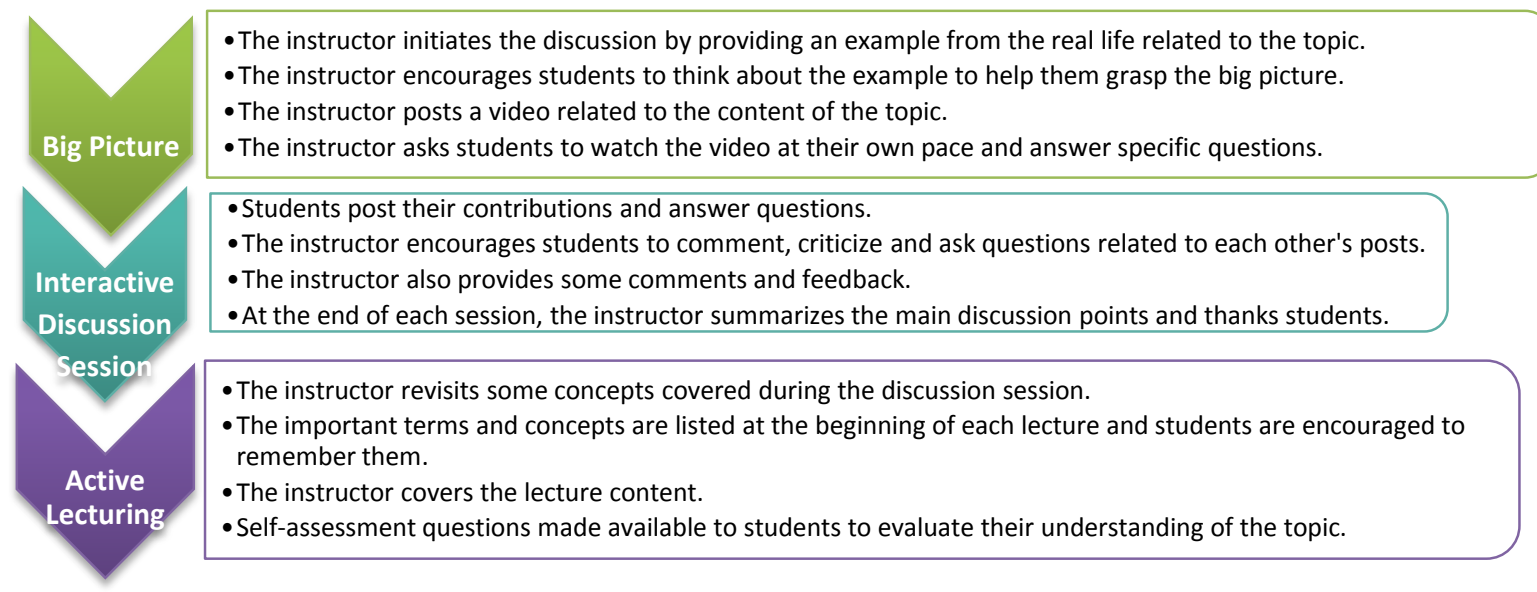

Figure 1. The cycle of the flipped learning activities. 

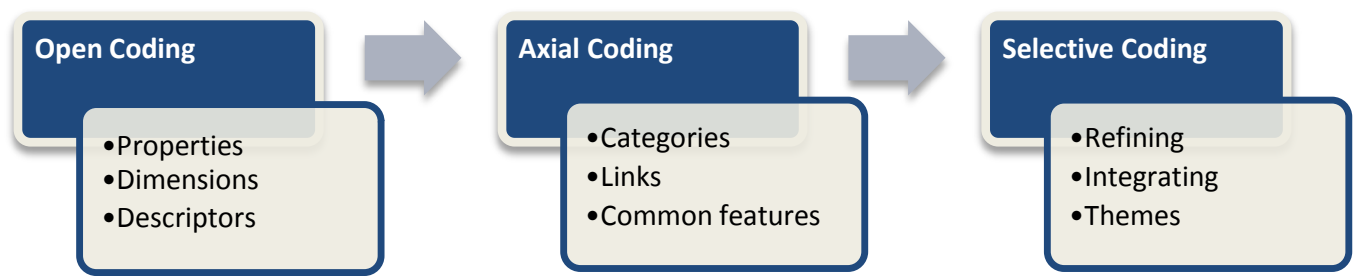

Figure 2. Stages of the constant comparison analysis.

third stage (i.e., selective coding), the researcher develops themes to represent the content of each group of data.

\subsection{Students' Perceptions and Educational Benefits of the Proposed Approach}

The first impression after the analysis of the data is that almost all students agreed that the flipped learning activities helped them better understand the concepts of the course in an interactive and collaborative learning environment. The results were grouped into two main themes: benefits and limitations. From the point view of the students, the educational benefits of using social media applications as flipped classroom approach can be summarized in the following:

- Activation of prerequisite knowledge: the activities helps students recall prerequisite knowledge required to understand the course content. It helps also link the concepts under study with examples and analogies from the real world. The analysis of the results also highlights the benefits of the activities in helping students to be familiar with the new terms and concepts (students were not native speakers of English).

- Support Self-Regulated Learning: students watch videos at their own pace. They can ask questions at any time and receive instant feedback from the instructor and other students in the discussion group. This encourages them to value the importance of self-regulated learning skills, such as peer-learning and help-seeking, in collaborative learning environments, and it helps them to have more control over the learning process.

- Collaborative learning environment: the discussion sessions were not completely predetermined by the instructor but rather depend on students' interactions and postings during the sessions. The instructor encouraged students to ask questions related to the contributions posted by other students, which in turn supported collaborative learning.

- Removing barriers between students and instructors: students are encouraged to be active learners, and therefore the role of the instructor was shifted to become a facilitator rather than a dominator for the learning process. It has been observed from students' questions and interactions that students felt they are more welcomed and this in turn made them more proactive.

\subsection{Limitations and Drawbacks of the Proposed Approach}

Although students consider the flipped learning approach as an innovative method of transforming the traditional classroom, the results of the analysis revealed some limitations and drawbacks of this approach, which can be outlined in the following:

- More load on the side of the teacher: the experience of the instructor in managing the group revealed that it was difficult to follow the discussion all the time, especially if all students are simultaneously providing contributions in the same session. The larger the discussion group, the more difficult to manage.

- Internet connection problems: a few number of students experienced internet connection problems at some stage. It happened in a number of discussion sessions that some students could not be able to participate in the discussion due to some internet connection problems.

- Some students copy from the internet: it has been observed after the analysis of the content of each discussion session that some posts were copied from the internet. One of the explanations is that some students might fell that the instructor would mark their posts, or that they do not have enough confidence in their ability to provide valuable content.

- Some students were not comfortable: some students felt that they were monitored and their posts were being evaluated at some stage during the session. This problem had been observed in a number of discussion sessions. Some students took more time before they post their contributions and they try to avoid criticizing or asking questions about the instructor posts. 


\section{Conclusion and Recommendations}

The results of this study can serve as a framework to improve the adoption of flipped learning approaches, especially in health informatics education. Social media have the potential to improve the implementation of flipped classrooms if planned carefully. The social medial platform has to be selected carefully after consultations with students. Comparison between different social medial platforms is essential before planning any integration into the instructional approach. Students also need to feel that they are not monitored and evaluated but comfortable when posting their contributions.

Finally, implementing flipped learning using social media needs to be accompanied by learning analytics frameworks tailored to the use of social media in education. These frameworks can help analyze and visualize the data resulted from students' interactions with the social media platforms and therefore provide instant feedback to improve the learning process.

\section{Acknowledgements}

The author gratefully acknowledges Qassim University, represented by the Deanship of Scientific Research, on the material support for this research under the number (3413) during the academic year 1436 AH/2015 AD. The author also acknowledges and thanks the students who participated in this study.

\section{References}

Amresh, A., Carberry, A. R., \& Femiani, J. (2013). Evaluating the Effectiveness of Flipped Classrooms for Teaching CS1. Paper Presented at the Frontiers in Education Conference, Oklahoma City, 23-26 October 2013, 733-735. http://dx.doi.org/10.1109/fie.2013.6684923

Bahner, D. P., Adkins, E., Patel, N., Donley, C., Nagel, R., \& Kman, N. E. (2012). How We Use Social Media to Supplement a Novel Curriculum in Medical Education. Medical Teacher, 34, 439-444. http://dx.doi.org/10.3109/0142159X.2012.668245

Brady, K. P., Holcomb, L. B., \& Smith, B. V. (2010). The Use of Alternative Social Networking Sites in Higher Educational Settings: A Case Study of the E-Learning Benefits of Ning in Education. Journal of Interactive Online Learning, 9, 151170.

Bruns, A. (2008). Blogs, Wikipedia, Second Life, and beyond: From Production to Produsage (Vol. 45). Peter Lang.

Bryer, T. A., \& Zavattaro, S. M. (2011). Social Media and Public Administration: Theoretical Dimensions and Introduction to the Symposium. Administrative Theory \& Praxis, 33, 325-340. http://dx.doi.org/10.2753/ATP1084-1806330301

Cheston, C. C., Flickinger, T. E., \& Chisolm, M. S. (2013). Social Media Use in Medical Education: A Systematic Review. Academic Medicine, 88, 893-901. http://dx.doi.org/10.1097/ACM.0b013e31828ffc23

Flipped Learning Network (2014). The Four Pillars of FLIP'т . http://www.ssfudes.com/veille/leveilleur/wp-content/uploads/2014/09/FLIP_handout_FNL_Web.pdf

Galway, L. P., Corbett, K. K., Takaro, T. K., Tairyan, K., \& Frank, E. (2014). A Novel Integration of Online and Flipped Classroom Instructional Models in Public Health Higher Education. BMC Medical Education, 14, 181. http://dx.doi.org/10.1186/1472-6920-14-181

Guy, R. (2012). The Use of Social Media for Academic Practice: A Review of Literature. Kentucky Journal of Higher Education Policy and Practice, 1, 7.

Jones, R. (2009). Social Media Marketing 101, Part 1. Search Engine Watch, 16.

Kolb, S. M. (2012). Grounded Theory and the Constant Comparative Method: Valid Research Strategies for Educators. Journal of Emerging Trends in Educational Research and Policy Studies, 3, 83-86.

Lee, M. J., \& McLoughlin, C. (2010). Beyond Distance and Time Constraints: Applying Social Networking Tools and Web 2.0 Approaches to Distance Learning. In G. Veletsianos (Ed.), Emerging Technologies in Distance Education (Chap. 4, pp. 61-87). Edmonton: Athabasca University Press.

Lenhart, A., Purcell, K., Smith, A., \& Zickuhr, K. (2010). Social Media \& Mobile Internet Use among Teens and Young Adults. Millennials. Pew Internet \& American Life Project.

Liu, Y. (2010). Social Media Tools as a Learning Resource. Journal of Educational Technology Development and Exchange, 3, 101-114.

Mantas, J., Ammenwerth, E., Demiris, G., Hasman, A., Haux, R., Hersh, W. et al. (2010). Recommendations of the International Medical Informatics Association (IMIA) on Education in Biomedical and Health Informatics (1st Revision). Methods of Information in Medicine, 49, 105-120. http://dx.doi.org/10.3414/ME5119 
McLaughlin, J. E., Roth, M. T., Glatt, D. M., Gharkholonarehe, N., Davidson, C. A., Griffin, L. M. et al. (2014). The Flipped Classroom: A Course Redesign to Foster Learning and Engagement in a Health Professions School. Academic Medicine, 89, 236-243. http://dx.doi.org/10.1097/ACM.0000000000000086

Murray, P. J., Paton, C., Hansen, M., Elkin, P. L., \& Fernandez-Luque, L. (2011). Towards a Research Agenda for Social Media in Healthcare and Academia. Paper presented at the Workshop at MIE2011, 23th International Conference of the European Federation for Medical Informatics, Oslo, 28-31 August 2011.

Onwuegbuzie, A. J., Dickinson, W. B., Leech, N. L., \& Zoran, A. G. (2009). A Qualitative Framework for Collecting and Analyzing Data in Focus Group Research. International Journal of Qualitative Methods, 8, 1-21.

Paton, C., Bamidis, P., Eysenbach, G., Hansen, M., \& Cabrer, M. (2011). Experience in the Use of Social Media in Medical and Health Education. Contribution of the IMIA Social Media Working Group. Yearbook of Medical Informatics, 6, 21.

Poellhuber, B., Anderson, T., \& Roy, N. (2011). Distance Students’ Readiness for Social Media and Collaboration. The International Review of Research in Open and Distributed Learning, 12, 102-125.

Stone, B. B. (2012). Flip Your Classroom to Increase Active Learning and Student Engagement. Paper Presented at the Proceedings from 28th Annual Conference on Distance Teaching \& Learning, Madison.

Strayer, J. F. (2012). How Learning in an Inverted Classroom Influences Cooperation, Innovation and Task Orientation. Learning Environments Research, 15, 171-193. http://dx.doi.org/10.1007/s10984-012-9108-4

Veletsianos, G., \& Navarrete, C. (2012). Online Social Networks as Formal Learning Environments: Learner Experiences and Activities. The International Review of Research in Open and Distributed Learning, 13, 144-166.

WhatsApp Inc. (2015). About WhatsApp. https://www.whatsapp.com/about/

Williams, A., \& Katz, L. (2001). The Use of Focus Group Methodology in Education: Some Theoretical and Practical Considerations. International Electronic Journal for Leadership in Learning, 5.

Xu, C. (2013). Classroom Flipping as the Basis of a Teaching Model for the Course Mobile Application Development. World Transactions on Engineering and Technology Education, 11, 537-540. 